\title{
HUBUNGAN ANTARA WORK FAMILY INTEGRATION DAN MEANINGFUL WORK PADA REMOTE WORKER
}

\section{Feby Satya Wirawati dan Anissa Lestari Kadiyono}

Universitas Padjajaran (Unpad) Bandung Jawa Barat, Indonesia

Email: feby19001@mail.unpad.ac.id dan anissa.lestari@unpad.ac.id

\section{Abstract}

This study is intended to determine the relationship between work family integration and meaningful work. Work family integration will create a balance between work roles and family roles so that remote workers can feel balance in their lives and feel meaningful in their work. The number of participants in this study was 30 people with the sampling technique used was quota sampling. The instruments used in this study were Integration-Segmentation Preferences Supplies (Kreiner, 2000) and The Work and Meaning Inventory (Steger, 2012). Based on the results of the Somer's $d$ test, the results obtained were $p=0.032(p<0.05)$ with $d=$ 0.885 , Kendall's tau $p=0.033$ ( $p<0.05)$ with $\tau=0.887$ and the Spearman rank $0.014(p<0.05)$ with $r s=0.967$. This indicates that there is a relationship between work family integration and meaningful work.

Keywords: work family integration; meaningfull work; remote worker

\begin{abstract}
Abstrak
Penelitian ini dimaksudkan untuk mengetahui hubungan antara work family integration dan meaningfull work. Work family integration akan membuat keseimbangan antara peran kerja serta peran keluarga sehingga pekerja remote worker dapat merasakan keseimbangan dalam hidupnya serta merasakan kebermaknaan dalam pekerjaannya. Jumlah partisipan pada penelitian ini sebanyak 30 orang dengan teknik pengambilan sampel yang digunakan adalah total sampling. Instrumen yang digunakan dalam penelitian ini adalah Integration-Segmentation Preferences Supplies (Kreiner, 2000) dan The Work and Meaning Inventory (Steger, 2012). Berdasarkan hasil uji somer's d didapatkan hasil $\mathrm{p}=0.032(\mathrm{p}<0.05)$ dengan $\mathrm{d}=0.885$, kendall's tau $\mathrm{p}=0.033(\mathrm{p}<0.05)$ dengan $\tau=0.887$ dan spearman rank 0.014 $(\mathrm{p}<0.05)$ dengan $\mathrm{rs}=0.967$. Hal tersebut mengindikasikan terdapat hubungan antara work family integration dan meaningfull work.
\end{abstract}

Kata Kunci: work family integration; meaningfull work; remote worker

\section{Pendahuluan}

Perubahan global yang mempengaruhi dalam sistem kerja nasional berpengaruh pula pada kehidupan pribadi serta interaksi pekerja secara pribadi. Mulai dari permasalahan gender dalam bekerja, perkembangan teknologi telah menyebabkan 
kaburnya batas kehidupan kerja yang memungkinkan karyawan untuk bekerja kapan saja dan di mana saja, sehingga berkontribusi pada masalah jam kerja yang berlebihan, pembagian tugas dalam organisasi, peningkatan pekerjaan paruh waktu menyebabkan ketidakamanan kerja dan meningkatkan beban kerja karyawan (O'Driscoll, 2008). PBB (Llave \& Messenger, 2018) melaporkan bahwa sebanyak 41\% pekerja yang memilih bekerja sebagai remote worker memiliki tingkat stress yang tinggi hal ini juga dikuatkan oleh temuan Harvard Business Review (Maxfield \& Grenny, 2017) yang melakukan penelitian terhadap 1.100 pekerja dengan temuan bahwa 52\% pekerja yang belerja dari rumah cenderung memiliki perasaan tersisihkan dan merasa diperlakukan tidak baik serta tidak mampu dalam menangani konflik dengan rekan maupun atasannya.

Salah satu permsalahan dalam dunia kerja saat ini adalah karyawan berusaha untuk mencapai keseimbangan antara tuntutan pekerjaan dan tuntutan rumah. Keseimbangan ini diimpikan oleh seluruh karyawan baik yang bekerja dari perusahaan maupun bekerja dari rumah atau remote working. Penelitian menunjukkan bahwa karyawan dan organisasi mendapat manfaat ketika karyawan memiliki keseimbangan kehidupan kerja yang sehat (Ronald Burke, 2010). Baltes (Baltes, B. B., Briggs, Huff, Wright, \& Neuman, 1999) menemukan bahwa karyawan mengalami peningkatan kepuasan kerja dan pemimpin organisasi melaporkan sikap karyawan yang lebih baik, meningkatkan kinerja kerja, dan mengurangi biaya ketika kebijakan keseimbangan antara kerja dan kehidupan keluarga diterapkan dalam organisasi.

Selama ini untuk meraih keseimbangan antara kehidupan kerja dan kehidupan keluarga merupakan hal yang hampir mustahil terjadi. Pengusaha didorong untuk membuat keseimbangan antara bekerja dan keluarga menjadi mungkin (Zedeck \& Mosier, 1990). Bahkan, sejak tahun 1999, Departemen Tenaga Kerja AS merekomendasikan agar para pemimpin bisnis untuk dapat membuat sistem dimana dapat membantu karyawan mengelola keseimbangan kerja dan non-kerja untuk mempertahankan kinerja serta bakat pekerja. Salah satu bentuk kebijakan yang perusahaan berikan adalah jadwal kerja serta tempat kerja yang fleksibel.

Jam kerja yang fleksibel dan dapat dilakukan dirumah memungkinkan seorang karyawan dapat mengontrol di mana, kapan, dan bagaimana pekerjaan dilakukan, membuat peran pekerja dalam pekerjaannya serta peran dalam keluarganya menjadi tidak jelas batasannya atau kabur. Menurut Burke (Peter J. Burke, 1991), "koneksi negatif" antara identitas peran yaitu, batasan spasial/waktu, kontradiksi makna, dan komitmen ganda - memperburuk dampak dari interupsi. Bayangkan seorang anak memanggil ibunya saat rapat kerja, sehingga menyela peran pekerjaan yang tengah dilakukannya. Sang ibu tidak dapat berada di dua tempat sekaligus (dalam batasan spasial/waktu) dan tidak dapat menggabungkan makna "ibu" dan "pekerja" menjadi identitas utama sehingga terjadi kontradiksi, yang membuat peran ganda sekaligus. ia akan mengalami konflik dan harus memilih antara peran orang tua atau peran pekerjaan. Hal ini serupa dengan penyataan Williams (Williams \& Alliger, 1994) bahwa memindahkan peran ibu dan pekerja yang tersegmentasi memiliki efek langsung dan negatif pada tugas dan suasana hati. 
Harrington (Bailyn \& Harrington, 2004) mengemukakan bahwa work family integration adalah hubungan pekerjaan, keluarga dan masyarakat yang mempertimbangkan serta mengatur pekerjaan dan keluarga dengan cara memenuhi kebutuhannya secara adil baik bagi pria maupun wanita. Work family integration dapat dilakukan untuk menghindari konflik serta mencapai keseimbangan antara peran pekerjaan dan juga peran dalam rumah serta bentuk sikap untuk menghindari stress yang tidak semestinya dan dapat menikmati setiap peran yang ada sehingga individu dapat mencapai keseimbangan serta memiliki kebermaknaan dalam pekerjaannya.

Karyawan dengan keluarga biasanya berusaha mencapai rasa keseimbangan pada setiap peran yang dijalani. Perasaan keseimbangan ini biasanya sulit tercapai ketika pekerjaan dan kehidupan rumah tumpang tindih karena ada tujuan bersama antara apa yang ingin dicapai seseorang di rumah dan apa yang ingin dicapai di tempat kerja (Munn, 2012). Ketika seseorang memiliki tujuan atau makna yang menyeluruh dalam hidupnya, tujuan ini memberikan hubungan yang erat antara berbagai sisi kehidupan. Kebermaknaan dapat dicapai melalui berbagai sisi seperti keluarga, pekerjaan, dan domain kehidupan lainnya. Makna juga dapat membaurkan satu domain ke domain lainnya (Grady \& McCarthy, 2008). Chalofsky (Munn, 2012) menjelaskan bahwa menemukan kebermaknaan di tempat kerja dapat berhubungan dengan alasan dasar mengapa orang bekerja dan dapat berbeda dari setiap orang misalnya mencakup nilainilai pribadi, memperluas rangkaian keterampilan, merasakan rasa kebersamaan, menemukan keseimbangan, pertumbuhan pribadi, dan pengembangan.

Beberapa tahun terakhir, perusahaan telah mengambil langkah-langkah untuk menyediakan tempat kerja yang bermakna dengan membantu karyawan menemukan keseimbangan dalam kehidupan mereka. Kebijakan ini meliputi cuti untuk orang tua, kesempatan kembali bekerja paruh waktu, dan penitipan anak di tempat bekerja. Organisasi yang menyediakan kebijakan keseimbangan anatara kerja-rumah, dapat membantu membuat tempat kerja lebih bermakna. Singkatnya, bermaknaan dalam kerja mempengaruhi nilai-nilai yang positif bagi individu dan tujuan menyeluruh dalam kehidupan, serta dalam kehidupan rumah tangga (Munn, 2012).

Cara seseorang menjalani kehidupannya berkontribusi pada kemampuan seseorang untuk menemukan kebermaknaan dalam pekerjaannya. Hal ini dapat dilihat dari keseimbagan antara peran yang dijalaninya dalam pekerjaan serta dalam keluarganya apakah individu tersebut mengintegrasikan antara perannya dalam keluarga dan juga pekerjaannya. Dengan demikian dapat dikatakan work family integration mempunyai hubungan dengan meaning of work pada seorang pekerja khususnya remote worker. Tujuan dari penelitian ini adalah untuk menelaah hubungan antara work family integration dengan meaning of work pada remote worker.

\section{Metode Penelitian}

Penelitian ini menggunakan pendekatan kuantitatif dengan desain penelitian korelasional, studi korelasional dalam penelitian ini digunakan untuk menguraikan dan mengukur seberapa besar tingkat hubungan antara variabel dalam penelitian ini variabel 
yang diukur adalah work family integration dan variabel meaningfull work. Penelitian ini menggunakan teknik pengambilan sampel total dimana terdapat 30 partisipan yang seluruhnya terdiri dari contributor pada media TV X di Jawa Barat. Partisipan terdiri dari 26 Laki-laki dan 4 Perempuan. Work family integration diukur dengan menggunakan Integration-Segmentation Preferences Supplies (Kreiner, 2000) yang kemudian skala ini dikembangkan oleh Eddleston (2015). Instrumen tersebut terdiri dari dimensi Integration-Segmentation Preferences (4 item, $\alpha=0.91$ ) dan IntegrationSegmentation Supplies (4 item, $\alpha=0.94$ ). Meaningfull work diukur dengan menggunakan The Work and Meaning Inventory (WAMI) (Steger, 2012). Instrumen tersebut terdiri dari tiga dimensi yaitu Positive meaning (4 item, $\alpha=0.92$ ), Meaning making through work ( 3 item, $\alpha=0.82$ ) dan Greater good motivations ( 3 item, $\alpha=0.82$ ).

\section{Hasil dan Pembahasan}

\section{A. Hasil Penelitian}

Tabel dibawah ini menunjukkan hasil analisis statistik deskriptif yang digunakan untuk memberikan gambaran umum mengenai data demografi responden.

Tabel 1

Data Demografi Partisipan

\begin{tabular}{lll}
\hline $\begin{array}{l}\text { Jenis Kelamin } \\
\text { Laki-laki }\end{array}$ & 26 & $(87 \%)$ \\
$\quad$ Perempuan & 4 & $(13 \%)$ \\
$\begin{array}{l}\text { Status Pernikahan } \\
\text { Lajang }\end{array}$ & 3 & $(43 \%)$ \\
$\quad$ Menikah & 27 & $(57 \%)$ \\
Jumlah Anak & & \\
$\quad$ Belum memilki anak & 5 & $(17 \%)$ \\
1 Anak & 7 & $(23 \%)$ \\
2 Anak & 17 & $(53 \%)$ \\
3 Anak & 2 & $(7 \%)$ \\
\hline
\end{tabular}

Hipotesis penelitian diuji dengan menggunakan uji korelasi, untuk menentukan apakah terdapat hubungan antara work family integration dengan meaningfull of work. Hipotesis penelitian ini adalah terdapat hubungan antara work family integration dengan meaningfull of work.

Tabel 2

Hasil Uji Korelasi Variabel Work Family Integration dan Meaningfull of Work

\begin{tabular}{|c|c|c|c|c|c|}
\hline \multicolumn{2}{|c|}{ somer's d } & \multicolumn{2}{|c|}{ Kendall's Tau } & \multicolumn{2}{|c|}{ Spearman's Rho } \\
\hline $\mathrm{d}$ & $p$ & $T$ & $p$ & $\rho$ & $P$ \\
\hline 0.885 & 0.032 & 0.887 & 0.033 & 0.967 & 0.014 \\
\hline
\end{tabular}

Tabel 2 menunjukkan hasil uji korelasi dengan menggunakan uji somer's d, uji Kendall's Tau dan Spearman's Rho. Pada hasil uji somer's d didapatkan hasil 
$\mathrm{p}=0.032(\mathrm{p}<0.05)$ dengan $\mathrm{d}=0.885$, sementara pada hasil Kendall's Tau didapatkan nilai koefisien sebesar $T=0.887$ dengan nilai signifikansi yaitu $p=0.003 \quad(p<0.05)$ Sementara untuk hasil uji dengan menggunakan Spearman's Rho, didapatkan nilai koefisien korelasi antara kedua variabel yang diteliti yaitu sebesar $\rho=0.967$ dengan nilai signifikansi $p=0.014(\mathrm{p}<0.05)$. Ketiga hasil pengujian statistik menunjukkan nilai signifikasi uji korelasi yang selaras dimana p-value dari kedua pengujian menunjukkan angka dibawah 0.05 atau $\mathrm{p}<0.05$. Selain itu, hasil uji korelasi pada kedua teknik uji statistik yakni Kendall's Tau dan Spearman's Rho menunjukkan nilai koefisien korelasi yang selaras, dimana kedua pengujian menghasilkan angka koefisien korelasi dengan taraf yang tinggi $(\mathrm{d}=0.885, T=0.887$ dan $\rho=0.967)$. Sehingga, dapat diputuskan bahwa $\mathrm{H}_{0}$ ditolak. Hasil tersebut menunjukkan bahwa variabel work family integration dengan meaningfull of work memiliki hubungan yang signifikan, dengan taraf keeratan hubungan yang tinggi.

\section{B. Pembahasan}

\section{Work Family Integration}

Work family integration mengacu pada Work-family border theory (Teori perbatasan kerja-keluarga) dimana teori ini mengacu pada perbatasan antara domain kehidupan keluarga dan pekerjaan. Batasan ini dapat bersifat fisik, temporal, atau psikologis. Misalnya, di mana dan kapan pekerjaan dilakukan dan menetapkan aturan untuk perilaku psikologis (Clark, 2000). Teori ini mengasumsikan bahwa individu mengadopsi border-keeping strategies. Dengan kata lain, individu dapat ditempatkan pada kontinum yang mengidentifikasi segmentasi dan integrasi. Batas-batas yang ketat, domain-domain kehidupan yang terisolasi (tersegmentasi) dan batas-batas transenden memungkinkan penyeberangan perbatasan terus menerus (integrasi). Integrasi berarti ada permeabilitas perbatasan yang tinggi dan identitas temporal, spasial, dan perbatasan yang kabur antara domain kehidupan. Manfaat dalam work family integration ini adalah bahwa kemungkinan terkait dengan fleksibilitas karyawan dan mengatur pengaturan peran kerja serta peran keluarga individu.

Integrasi dilambangkan dengan peran yang dibedakan secara lemah (kontras rendah), tidak terikat pada tempat dan waktu tertentu (batas fleksibel), dan memungkinkan interupsi peran-silang (batas permeabel). Peran yang sangat terintegrasi cenderung memiliki identitas yang sama, tertanam dalam konteks yang sama, dan tumpang tindih di lokasi fisik dan keanggotaan dari setiap peran. Mengingat fleksibilitas antara batas peran yang tinggi dan permeabilitas, transisi antara peran cenderung relatif sering dan mungkin tidak dapat diprediksi (misalnya, pekerja berbasis rumahan meluangkan waktu untuk merawat anak yang menangis).

Kontras yang rendah antara identitas peran dan fleksibilitas dan permeabilitas batas-batas peran, proses transisi untuk peran yang terintegrasi cenderung lebih sulit daripada peran yang segmentasi. Dengan demikian, proses 
transisi keluar masuknya peran tidak terlalu rumit. Ahrentzen menemukan bahwa pekerja berbasis rumahan cenderung melakukan ritual yang relatif sederhana untuk mendapatkan motivasi untuk mulai bekerja (mis., Minum kopi, baca koran) (Ahrentzen, 1990). Peralihan peran pada work family integration dapat terjadi dengan cepat, dengan sedikit atau tanpa kesadaran. Sebagai contoh, seorang manajer pada satu rapat merupakan seorang bos dan ketika berada di rapat atau pertemuan selanjutnya dia adalah rekan kerja, perpindahan ini hanya memerlukan sedikit upaya psikologis (dan fisik).

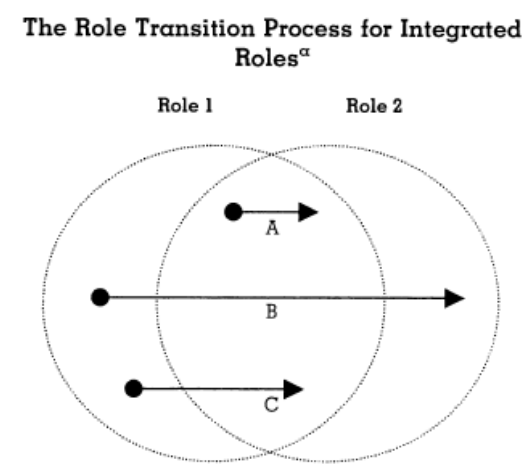

\section{Gambar 1}

Transisi Peran

Faktor yang memengaruhi besarnya transisi adalah gerakan transisi melintasi peran secara bersama atau eksklusif. Seperti yang diilustrasikan oleh Gambar 1, peran yang sangat terintegrasi (tetapi tidak sepenuhnya) terdiri dari tiga bidang terpisah: (1) area eksklusif untuk peran 1, (2) area eksklusif untuk peran 2, dan (3) area tumpang tindih antara peran. Meningkatnya area yang tumpang tindih meningkatkan pula area kekaburan peran dan kesulitasn untuk transisi menurun. Gambar 3 menggambarkan tiga variasi transisi antara peran terintegrasi; masing-masing berbeda dalam tingkat di mana tumpang tindih identitas peran. Pada satu peran 1 (transisi A), transisi peran dalam area yang tumpang tindih mungkin tidak memiliki arti sama sekali karena bagian-bagian identitas dan bertumpang tindih tidak mengalami tidak mengalami perubahan psikologis atau fisik yang signifikan. Pada peran 2 (transisi B), transisi antara dua area eksklusif mungkin tampak mirip dengan transisi antara peran yang tersegmentasi karena ada beberapa perubahan psikologis atau fisik, meskipun sebagian tumpang tindih dalam identitas peran. Opsi ketiga peran 3 (transisi C) terjadi ketika seseorang bergerak dari area eksklusif dari satu peran ke area yang tumpang tindih dengan peran lain (atau sebaliknya).

Kekaburan peran dalam work family integration memiliki peran yang besar (Ashforth, Kreiner, \& Fugate, 2000). Batas-batas yang sangat fleksibel dan permeable, ditambah dengan identitas peran yang tumpang tindih dan set peran dan konteks yang terkait, dapat menumbuhkan kebingungan dan kecemasan tentang identitas peran mana yang harus atau paling menonjol. Contoh utama 
adalah multiplex relationship yaitu, hubungan yang didasarkan pada lebih dari satu set peran. Dorsey (Ashforth et al., 2000) menggambarkan tantangan yang dialami oleh seorang penjual Xerox yang membuat kesepakatan dengan pelanggan lama yang telah menjalin persahabatan dengannya. Pelanggan memandangnya sebagai teman dan mengharapkan harga yang sangat bagus, sedangkan dia, sebagai penjual, diharapkan mendapatkan kesepakatan yang sangat menguntungkan. Dengan demikian, kekaburan peran dapat mengakibatkan kecemasan, dan bahkan rasa malu, jika seseorang diminta untuk berpindah-pindah atau secara bersamaan memberlakukan peran (Gross \& Stone, 1964).

Work-family Integration adalah kecenderungan individu untuk menggabungkan antara peran bekerja dan juga peran dalam keluarga. Ada dua elemen dalam Work-family Integration, yaitu Integration-Segmentation Preferences dan Integration-Segmentation Supplies. Alat ukur yang digunakan adalah Integration-Segmentation Preferences Supplies yang dibuat oleh Kreiner yang kemudian dikembangkan oleh Eddleston. Kreiner (Kreiner, 2006) mengembangkan kuesioner dengan dimensi Integration-Segmentation Preferences Supplies untuk menilai apakah individu termasuk kedalam Workfamily Integration atau Work-family Segmentation.

\section{Meaning of Work}

Tujuan hidup adalah menemukan makna (meaning). Psikolog Victor Frankl menggambarkan tujuan hidup manusia yaitu menemukan sesuatu dalam hidup yang membawa perasaan positif dan kemudian membayangkan kesuksesan dan pemenuhan tujuan yang dikatakan (Frankl, 1963).

Mencari nafkah dengan melakukan pekerjaan adalah komponen utama dalam menemukan makna (meaning). Para peneliti memperdebatkan kewajiban moral dan etika dari tempat kerja dalam membantu karyawannya untuk mengembangkan kebermaknaan (Yeoman, 2014). Hackman dan Oldham (Hackman \& Oldham, 1976) mengemukakan kondisi psikologis yang diperlukan agar pekerja termotivasi dan puas pada pekerjaannya, kondisi tersebut adalah persepsi mereka tentang kebermaknaan (yang dipengaruhi oleh tugas pekerjaan, variasi keterampilan, dan identitas tugas). Selain itu Kahn (Kahn, 1990) memperkenalkan konsep employee engagemnet, dimana, salah satu dari tiga mekanisme psikologis yang menghubungkan individu dan dirinya dalam peran pekerjaan adalah kebermaknaan (bersama dengan ketersediaan dan keamanan). Brown \& Lent (Brown \& Lent, 2016) menghubungkan kesejahteraan eudemonik dengan makna (meaning), dan menyimpulkan bahwa kesejahteraan eudemonik dicapai dengan menjalani kehidupan yang baik atau bermakna (bersama dengan memiliki rasa panggilan dan keterlibatan). Duffy, Autin, dan Bott, menemukan bahwa kemauan kerja yang dimediasi oleh kecocokan orang-lingkungan dan makna kerja menyumbang $82 \%$ dari varians dalam kepuasan kerja ketika diuji menggunakan pemodelan persamaan struktural. Teori-teori ini telah 
menyarankan pentingnya kebermaknaan di tempat kerja untuk mencapai keterlibatan, kesejahteraan, motivasi, dan kepuasan kerja.

Chalofsky (Munn, 2012) menemukan bahwa tiga tema utama muncul dalam kebermaknaan pekerjaan. Tema tersebut adalah pengalaman kerja yang bermakna dan membentuk kehidupan yang terintegrasi, rasa percaya diri yang kuat, karya dalam pekerjaannya serta rasa keseimbangan antara pekerjaan dan keluarga.

Meaningfulness of Work datang dengan kepuasan mengetahui bahwa tugas harian yang dilakukan berkontribusi untuk kebaikan yang lebih besar (Munn, 2012). Ini mengharuskan organisasi untuk mengambil pandangan yang lebih luas dan lebih mendalam tentang karyawan mereka, karena ada hubungan yang saling tergantung antara karyawan dan organisasi, di mana karyawan mencari organisasi yang tidak hanya akan merawat mereka, tetapi juga menjaga keluarga mereka dengan memahami perlunya keseimbangan kehidupan kerja (Munn, 2012). Budaya organisasi di mana karyawan dapat menjadi diri mereka sendiri, berinteraksi dengan rekan kerja, dan berbicara tentang kehidupan pribadi mereka berkontribusi pada kemampuan seseorang untuk menemukan Meaningfulness of Work (Munn, 2012). Dalam beberapa tahun terakhir, organisasi telah mengambil langkah-langkah untuk menyediakan tempat kerja yang bermakna dengan membantu karyawan menemukan keseimbangan dalam kehidupan mereka. Tunjangan dan kebijakan ini termasuk cuti orang tua yang dilindungi pekerjaan, kesempatan paruh waktu untuk kembali bekerja, dan penitipan anak di tempat, untuk beberapa nama. Organisasi yang menyediakan kebijakan keseimbangan kerja-rumah yang bermanfaat ini, dapat membantu membuat tempat kerja lebih bermakna.

Meaningful of Work adalah pandangan bagaimana individu memaknai pekerjaanya sehingga dapat berpengaruh positif dalam kehidupannya, mempunyai makna bagi individu dalam perkembangan dan pertumbuhannya dan juga pekerjaan mempunyai tujuan yang saling berhubungan dengan tujuan hidup individu tersebut. Alat ukur yang digunakan adalah The Work and Meaning Inventory (WAMI) yang dibuat oleh Steger (Steger, Dik, \& Duffy, 2012). Steger mengembangkan skala WAMI dimana skala ini terdiri tiga dimensi yaitu Positive meaning, meaning making through work dan Greater good motivations.

Berdasarkan hasil perhitungan diketahui bahwa work family integration dengan meaningfull of work memiliki hubungan yang signifikan dengan taraf keeratan hubungan yang tinggi. Kebermaknaan dan pemenuhan kebutuhan adalah hal yang memotivasi individu untuk dapat mengintegrasikan peran keluarga serta peran dalam pekerjaannya. Proses integrasi ini tidak mungkin dilakukan tanpa koordinasi dengan organisasi serta dedikasi akan setiap peran yang dijalani. Bukan tidak mungkin remote worker mengalami kendala dalam pekerjaannya kendala yang paling terlihat dalam remote worker adalah kekaburan peran antara peran keluarga serta peran dalam pekerjaannya. 
Fleksibilitas jam kerja memungkinkan individu untuk berpindah peran dari satu peran ke peran lainnya dan memungkinkan individu untuk berintegrasi diseluruh domain peran mereka.

Hasil penelitian ditemukan bahwa remote worker berada pada domain work family integration dengan tingkatan yang moderat atau cukup. Dengan demikian, meskipun peran pekerjaan dan keluarga dapat dikatakan terintegrasi secara baik untuk pekerja remote, tetapi pekerja remote tetap dapat menerapkan batasan-batasan sehingga kekaburan peran tidak terlalu terlihat dalam lingkungan pekerjaannya yang mengakibatkan konflik baik dalam keluarga maupun dari pekerjaannya. Maka, dalam penelitian ini transisi yang terjadi adalah transisi $\mathrm{B}$, dimana transisi antara dua area eksklusif mungkin tampak mirip dengan transisi antara peran yang tersegmentasi karena ada beberapa perubahan psikologis atau fisik, meskipun sebagian tumpang tindih dalam identitas peran. Hasil penelitian Eddleston (Eddleston \& Mulki, 2017) menunjukan bahwa kemampuan untuk membagi beberapa aspek pekerjaan dan keluarga pada para pekerja remote membatasi konflik pada pekerjaan serta keluarga mereka.

Pencarian untuk memperoleh dan keseimbangan antara kehidupan kerja dan kehidupan keluarga adalah proses pengembangan berkelanjutan. Partisipan dalam penelitian ini merasakan kebermaknaan yang tinggi terhadap pekerjaannya. dapat dikatakan mereka mengalami lebih sedikit konflik keluarga yang bekerja, lebih banyak merasakan keseimbangan keluarga dalam bekerja. Hal yang sama berlaku ketika mereka merasakan arti yang lebih bermakna dalam kehidupan rumah/keluarga mereka. Chalofsky (Munn, 2012) menemukan bahwa tiga tema utama muncul dalam kebermaknaan pekerjaan. Tema tersebut adalah pengalaman kerja yang bermakna dan membentuk kehidupan yang terintegrasi, rasa percaya diri yang kuat, karya dalam pekerjaannya serta rasa keseimbangan antara pekerjaan dan keluarga. Pada pekerja remote, mereka dapat mengintegrasikan antara peran keluarga dan juga peran pekerjaan sehingga meminimalkan konflik serta mengalami keseimbangan dalam kehidupannya sehingga pekerja remote ini dapat merasakan kebermaknaan yang tinggi terhadap pekerjaannya.

\section{Kesimpulan}

Remote worker pada pekerja media TV X berada pada domain work family integration yang cukup dimana meskipun peran pekerjaan dan keluarga dapat dikatakan terintegrasi secara baik untuk pekerja remote, tetapi pekerja remote tetap dapat menerapkan batasan-batasan sehingga kekaburan peran tidak terlalu terlihat dalam lingkungan pekerjaannya. Adapun keseimbangan yang dimiliki oleh para remote worker ini menjadikannya lebih mengalami keseimbangan antara peran keluarga serta peran pekerjaannnya sehingga meminimalisir konflik yang terjadi pada lingkungan pekerjaan serta ingkungan keluarganya. Keseimbangan yang diperoleh oleh para remote worker 
Hubungan Antara Work Family Integration dan Meaningful Work pada Remote Worker

ini kemudian membuat para remote worker merasakan kebermaknaan yang tinggi pada pekerjaannya. 


\section{BIBLIOGRAFI}

Ahrentzen, Sherry Boland. (1990). Managing Conflict by Managing Boundaries. Environment and Behavior, 22(6), 723-752. https://doi.org/10.1177/0013916590226001 Google Scholar

Ashforth, Blake E., Kreiner, Glen E., \& Fugate, Mel. (2000). All in a day's work: Boundaries and micro role transitions. Academy of Management Review, 25(3), 472-491. https://doi.org/10.5465/AMR.2000.3363315 Google Scholar

Bailyn, Lotte, \& Harrington, Mona. (2004). Redesigning work for work-family integration. Community, Work and Family, 7(2), 197-208. https://doi.org/10.1080/1366880042000245470 Google Scholar

Baltes, B. B., Briggs, T. E., Huff, J. W., Wright, J. A., \& Neuman, G. A. (1999). Editorial. Journal of Applied Psychology, 84(4), 496-513. https://doi.org/10.15446/rcp.v25n1.56276 Google Scholar

Brown, Steven D., \& Lent, Robert W. (2016). Vocational Psychology: Agency, Equity, and Well-Being. Annual Review of Psychology, 67(1), 541-565. https://doi.org/10.1146/annurev-psych-122414-033237 Google Scholar

Burke, Peter J. (1991). Identity Processes and Social Stress. American Sociological Review, 56(6), 836. https://doi.org/10.2307/2096259 Google Scholar

Burke, Ronald. (2010). Do managerial men benefit from organizational values supporting work-personal life balance? Gender in Management, 25(2), 91-99. https://doi.org/10.1108/17542411011026267 Google Scholar

Clark, Sue Campbell. (2000). Work/Family Border Theory: A New Theory of Work/Family Balance. Human Relations, 53(6), 747-770. https://doi.org/10.1177/0018726700536001 Google Scholar

Eddleston, Kimberly A., \& Mulki, Jay. (2017). Toward Understanding Remote Workers' Management of Work-Family Boundaries: The Complexity of Workplace Embeddedness. Group \& Organization Management, 42(3), 346-387. https://doi.org/10.1177/1059601115619548 Google Scholar

Grady, Geraldine, \& McCarthy, Alma M. (2008). Work-life integration: Experiences of mid-career professional working mothers. Journal of Managerial Psychology, 23(5), 599-622. https://doi.org/10.1108/02683940810884559 Google Scholar

Gross, Edward, \& Stone, Gregory P. (1964). Embarrassment and the Analysis of Role Requirements. American Journal of Sociology, 70(1), 1-15. https://doi.org/10.1086/223733 Google Scholar

Hackman, J. Richard, \& Oldham, Greg R. (1976). Motivation through the design of work: test of a theory. Organizational Behavior and Human Performance, 16(2), 
250-279. https://doi.org/10.1016/0030-5073(76)90016-7 Google Scholar

Kahn, William A. (1990). Psychological conditions of personal engagement and disengagement at work. Academy of Management Journal, 33(4), 692-724. https://doi.org/10.5465/256287 Google Scholar

Kreiner, Glen E. (2006). Consequences of work-home segmentation or integration: a person-environment fit perspective. Journal of Organizational Behavior, 27(4), 485-507. https://doi.org/10.1002/job.386 Google Scholar

Llave, Oscar Vargas, \& Messenger, Jon. (2018). 1757b Working anytime, anywhere: the effects on the world of work. A219.2-A220. https://doi.org/10.1136/oemed-2018icohabstracts.623 Google Scholar

Maxfield, David, \& Grenny, Joseph. (2017). A Study of 1,100 Employees Found That Remote Workers Feel Shunned and Left Out. Harvard Business Review, 1-5. Retrieved from https://hbr.org/2017/11/a-study-of-1100-employees-found-thatremote-workers-feel-shunned-and-left-out Google Scholar

Munn, Sunny L. (2012). Book review: Neal E Chalofsky, Meaningful Workplaces: Reframing How and Where We Work. Work, Employment and Society, 26(3), 542-543. https://doi.org/10.1177/0950017012438582 Google Scholar

O'Driscoll, Pam Allis Michael. (2008). Article information : 23(3), 273-291. Retrieved from https://www.emerald.com/insight/content/doi/10.1108/02683940810861383/f $\mathrm{ull} / \mathrm{html}$

Steger, Michael F., Dik, Bryan J., \& Duffy, Ryan D. (2012). Measuring Meaningful Work. Journal of Career Assessment, 20(3), 322-337. https://doi.org/10.1177/1069072711436160 Google Scholar

Williams, Kevin J., \& Alliger, George M. (1994). Role Stressors, Mood Spillover, and Perceptions of Work-Family Conflict in Employed Parents. Academy of Management Journal, 37(4), 837-868. https://doi.org/10.5465/256602 Google Scholar

Yeoman, Ruth. (2014). Conceptualising Meaningful Work as a Fundamental Human Need. Journal of Business Ethics, 125(2), 235-251. https://doi.org/10.1007/s10551-013-1894-9 Google Scholar

Zedeck, Sheldon, \& Mosier, Kathleen L. (1990). Work in the family and employing organization. American Psychologist, 45(2), 240-251. https://doi.org/10.1037/0003-066X.45.2.240 Google Scholar 


\section{Copyright holder:}

Feby Satya Wirawati dan Anissa Lestari Kadiyono (2021)

\section{First publication right:}

Journal Syntax Literate

This article is licensed under:

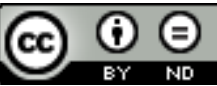

